\title{
Diversity in Uniform? - Gender and Sexuality Within the Berlin Police Force ${ }^{[1]}$
}

\author{
by Sonja M. Dudek \\ Bielefeld University
}

Sociological Research Online, Volume 12, Issue 1,

< http://umw. socresonline.org.uk/12/1/dudek.html>

doi:10.5153/sro. 1534

Received: 25 Jan 2006 Accepted: 12 Mar 2007 Published: 31 Jan 2007

\begin{abstract}
This article examines the significance of gender and sexuality within the German uniformed police. For a long time the police was regarded to be the classic domain of men, but since some years the police actively tries to employ more heterogeneous staff. These efforts result in a clear change of personnel: more and more women are working in the police. It is the aim of this article to firstly examine in which historical contexts gender and sexuality have been relevant categories within the police organisation. Secondly gender and sexuality in organisational theory, especially considering criticism of feminist organizational theory on classical concepts are discussed. Thirdly theories on micropolitical negotiations, processes of managing gender and sexuality are introduced and connected to the police. In the following part of this article two interview examples are presented and analysed, in which the significance of sexuality and gender today are discussed by female police officers.
\end{abstract}

\section{Keywords: Diversity, Gender, Sexuality, Police, Organisation}

\section{Introduction}

1.1 Yes, there is already something troubling in the heading of this article. It might be caused by a certain tension or even contradiction between the terms uniform and diversity. Is not one aim of being uniformed to look alike? Is not one purpose of uniforms to rather signify the function of the uniformed person, than to point out personal characteristics? Comparable tensions can be found within the organisation. Since 1990 the Berlin police as a classic bureaucratic organisation with the claim to treat all of it's members equal by applying the same neutral rules to everyone is confronted with special laws ${ }^{[2]}$ to promote women. Moreover despite the principle of rationality, there have been and still are reports ${ }^{[3]}$ and research studies ${ }^{[4]}$, which point out problematic aspects in dealing with diversity within the police force.

1.2 The aim of this paper is a discussion on gender and sexuality in the Berlin police. Following Scott (1986) gender is a relevant category on different levels; this paper especially concentrates on interaction and normative concepts concerning gender within the police force.

1.3 Sexuality and gender are closely intertwined. As Jackson (1999) argues, the division between homoand heterosexuality would not even make sense without gender. Scott's statement on gender, that it 'is a primary field within or by means of which power is articulated' (p. 1069) could be made for sexuality as well. Therefore heteronormativity can be described as a means by which heterosexuality is taken for granted to be the norm and all other behaviours and identifications seen as deviant or marginal. Butler (1990) points out the importance of understanding heterosexuality as a complex system of power, in which sex, gender and desire are closely intertwined.

1.4 In order to discuss gender and sexuality within the police organisation firstly a historical perspective on this topic is offered. This perspective illustrates how gender and sexuality were (made) relevant within the police at different historical times. Secondly the conception of ideal gender and sexuality neutral organisations gets criticised and different notions concerning organisations are offered. In a third part of this paper the focus of analysis is shifted to individual interactions within organisations, in which gender and sexuality are of importance. Some methodological reflections on a study the author conducted within the police are presented in the fourth part of the paper. Afterwards extracts from three interviews with homosexual and heterosexual policewomen are discussed. Some concluding remarks reflect on the different aspects discussed in the paper. 


\section{Gender - Sexuality - Policing: a historical perspective}

2.1 Even though it is not the aim of this article to mainly focus on historical aspects concerning the integration of women and homosexual officers in the Berlin police, I consider it necessary for a deeper understanding of organisational logics and processes, which are at stake here, to at least deliver some context information. I am not sure, if I would argue that there is something like a 'collective memory' of an organisation, but there are certainly routines and practices, which are of significance for organisations and their self perception over a long period of time. In this case: there have been negotiations around issues of gender and sexuality before the here presented data were collected, which are still influential on the organisation today. Therefore, I do not want to concentrate on single dates or discussions, but present some general characteristics of the integration of women in the German police.

2.2 The police was, for a long time, regarded to be the classic domain of (heterosexual) men and a rather homogeneous organisation. One reason for this perception was probably that it was one of the last state organisations, which opened itself for women. Not until 1978 women were employed in the uniformed police of Berlin and until the 90ies there were special conditions for the employment of women. Since the midnineties the Berlin police intensifies its efforts to recruit more heterogeneous staff by publicity campaigns, which especially address women.

2.3 Even though the police was one of the last organisations, which finally opened up for women, the history of women in the German police goes back until the beginning of the $20^{\text {th }}$ century. There have been certain historical times, in which women were considered capable of working as police officers and times in which they were denied all of the general qualification for police work, usually simply by referring to their gender. In general, it seems that women were often considered suitable for police work when no male applicants were available. In other words: Doubts about women's general ability to work in the police force often got raised if enough men were there to do the job. It can be analysed that in these times discussions on the 'nature' or the 'character' of women were brought up. This indicates that these discussions were based on ideology rather than on facts. However, concerning this contradictory practice, gender seems to be a highly flexible concept, which is used to allocate to certain jobs.

2.4 Moreover if women were considered capable to work as police officers paradoxically on the one hand the public opinion on women legitimizes their employment in the police as a good complement to their male colleagues. On the other hand exactly this public opinion justifies establishing special areas of operations for women. For a long time female officers were only responsible for areas, which were relatively close connected to social gender stereotypes. It was more social and welfare duties of almost motherly nature, which shaped the picture of women within the police. Therefore it was originally planned that the female uniformed police would be especially responsible to search female prisoners, to give information to citizens, to investigate sex crimes and crimes, in which children, adolescents and women were involved. But in reality it very often happened that female officers were employed in all areas of police work (see e.g. Berliner Polizei, Nr. 11/1953, p.9).

2.5 Today there are officially no gender specific jobs or treatment in the police. Due to laws to promote women, the employment rate of female officers is by nearly $40 \%$ each year, even though it has to be stressed that this high percentage of women can only be claimed for the minor positions within the police. It is still remarkable how few women are working in leading positions.

2.6 An historical perspective on homosexuality within the police is a difficult task, since there is very little literature concerning this topic. Open discussions on homosexuality in the police are a rather recent development. Even though this paper focuses on police intern developments, especially the issue of homosexuality demonstrates the impossibility of discussing internal affairs without taking into account societal developments. Concerning homosexuality this can be stressed for the $\S 175$, which has been part of the German law since 1871. This paragraph got increased by the Nazis and punished sexual behaviour between men. The $\S 175$ was hardly changed after the Second World War. In 1973 the $\S 175$ was weakened and not until 1994 it was abolished after 123 years of existence (Braun, 1995). Nevertheless since the police was responsible for executing this law, it's meaning for the internal dealing with homosexuality cannot be underestimated. As one result of this history the relationship between homosexuals and the police has been traditionally tensed. It is no coincidence that the first official group of gay and lesbian officers (Velspol) was founded in 1994, the group states on their webpage ${ }^{[5]}$ that they waited until the abolition of the $\S 175$ with making their group official. Since the 90 's there have been intensified police efforts to fight violence against homosexual people and in 1992 a full time job as a contact person for homosexual people was established within the Berlin police. Even though the researchers were told by homosexual officers that the former police president of Berlin denied the existence of homosexuality within the police until the end of the 90ies, today in most cases the existence of homosexuality in the police is no longer a taboo subject. 


\section{Gender and sexuality in organizations}

3.1 Based on Max Weber's conception of bureaucracy as rational, abstract and neutral, grounded on rules rather than judging on personal characteristics of its members or its customers, categories like sexuality and gender have for a long time been no subject of organizational analyses (see e.g. Burrell \& Hearn, 1989). Following the formal logic of rationality this abstinence makes sense, even though the relevance of gender and sexuality within organisations has been demonstrated in numerous analyses (e.g. Acker, 1991; Burrell, 1984; Cockburn 1993; Kanter, 1977; Rastetter, 1994; Wilz, 2002).

3.2 Feminist organizational theories have often criticized the theoretical blindness of classical organizational research towards categories like gender and sexuality. Acker (1991) criticizes: 'In organizational logic, both jobs and hierarchies are abstract categories that have no occupants, no human bodies, no gender' (p. 170). Moreover she concludes that not only gender, but sexuality as well is very often excluded from organizational analyses. Burrell (1984) expresses astonishment over the fact that sexuality, while playing such an important role in literature and everyday life, is given so little attention in the analysis of organisations. By reflecting on the history of some of the first organisations Burrell shows how the exclusion of sexuality and the attempt to control homosexuality was one of the first tasks of bureaucracy. On a structural level Acker (1991) shows how already the concept of a 'job' is deeply embedded in a heterosexual gendered substructure, she states: 'The closest the disembodied worker doing the abstract job comes to a real worker is the male worker whose life centers on his full-time, lifelong job, while his wife or another woman takes care of his personal need and his children' (p. 170). Historically the institution of career civil servants is embodied in the concept of bureaucracy mentioned above and e.g. implies a growing salary depending on age and an uninterrupted career. The above mentioned mechanism of implicit exclusion of women by constructing a 'male norm worker' is part of the historical developed division between male and female sphere. Nonetheless it is important to stress that this concept is not necessarily in favour of all men and problematic for all women, such a view would polarize and naturalize gender arrangements, which are far more complex and difficult. It is often neglected in this context that there are women, who do not wish to have children or do not stay at home. Even though it is obvious that such a job definition often reinforces classical gender arrangement in heterosexual relationships with children. But as Müller (1999) stresses a general perception of organisation and bureaucracy as anti-women has to be rejected in favour of more complex analyses of organisational practices.

3.3 Especially the focus on micropolitical negotiations among organisation members, which construct and affirm certain conceptions of gender and sexuality, has been fruitful to analyze constructions of gender as complex processes. In empirical studies on 'doing gender while doing the job' Leidner (1991) observes that most men had a stronger interest in keeping and stressing a certain difference, while women often try to minimize difference (see also Wetterer 1993; Heintz \& Nadai 1998). The attempt to naturalize gender difference is often made to legitimize existing power relations and to exclude individuals from certain jobs. Women in dominantly male-heterosexual organizations are often conceptualized as 'the other', which consists of everything, which is not welcome in the sphere of abstract work. In this argumentation it gets obvious that it is rather difficult to escape especially implicit gender specific stereotypes. Women are often demanded to incorporate difference and the presence of women is welcomed as 'erotic spice of everyday work' (Müller 1993, p. 111).

3.4 What does that mean for the police? Police organisations can be characterized as classical bureaucratic organisations following the definition of Weber. Police work is organised in hierarchical structures with written prescriptions of responsibilities and functions, a well defined rank order, detailed written rights and duties applicable to every job position, clear rules on promotion and employment, just to name some of the important characteristics (see Yearley 1995, p. 118-122). The German police has been and still is in some areas a male dominated organisation, which is changing due to more and more women working as police officers. One characteristic of the police concerning gender is a horizontal segmentation; hierarchy is one main gender separator. Following Rastetter (1994) male dominated organisation often show characteristics of male bonding and Connell (1995) remarks that homophobia is often one major element of male dominated groups.

\section{Methodology}

4.1 The analysis of individual reflections on the management of sexuality and gender was the aim of indepth interviews a colleague and I conducted with eight policewomen and homosexual officers in Berlin in 2002. The majority of respondents are members of a police organization for homosexual officers or organizations for policewomen. Most of the respondents were recruited with the help of contact persons within these organizations, some of the respondents were recruited through other officers.

4.2 The interviewers collected and analyzed the data using 'semi-focused interviews' (based on Witzel, 1985), trying to obtain narratives about everyday experience. The interviews started out with an open, 
narrative-generating question on how the interviewee came to choose to work as an officer. The following parts of the interviews focused on the daily routine of police work and on the experiences with colleagues and deputies. The last part of the interview concentrated on the membership of the officer in one of the above mentioned organizations and on reasons for this membership.

4.3 The interviews were analyzed according to Grounded Theory by Strauss and Corbin (1996). Grounded Theory makes it possible to discover underlying concepts in verbal data and differentiate them in their dimensions. The central topics generated from the data were self-presentation as an officer, handling of difference and attitudes towards the police/deputies. In this paper the first two dimensions are further explored.

4.4 Of course there are ethical issues, which have to be considered when conducting interviews on such a sensitive matter. First of all it is very important to guarantee anonymity in order to make it impossible for anyone who reads the interview passages to identify the interviewee. Therefore we changed all the names of persons and places and did not publish information the interviewees could be identified with. Interestingly most of our interviewees did not consider confidentiality an important matter, even though some of them talked about very personal and painful experiences. The reason for this could be that since our research was linked to university and not to the police organisation, the interviewees did not fear their colleagues would read their statements. Furthermore we conducted these interviews outside the police.

4.5 The data presented in this paper are taken from three interviews with homosexual and heterosexual policewomen. The reason for choosing these interviews is that they already demonstrate a variety of aspects on how women can experience and deal with difference within the police. Moreover the author considers it as important to offer some background information on the interviewee and their complex self representation, which makes it necessary to limit the presented interviews to three. The interview with officer Brown marks the interview, which describes the most discriminatory experience of all interviews I conducted within the police until today.

4.6 Even though I do not want to generalize the described experience in the interviews, they are also not singular ${ }^{[6]}$. In other words: patterns of dealing with possible differences and exclusions, which are described, can be found in the other interviews as well.

\section{Managing gender and sexuality while doing the job}

5.1 Even though the Berlin police officially promotes diversity, the question can be raised if gender and sexuality are still important categories within the police and how they are negotiated within the organisation. Nadai \& Heintz (1998) describe gender management of women and men in not gender stereotypical jobs as complex processes of doing and undoing gender. Gender has to be stressed or made insignificant depending on the situation and context of the interaction (Heintz \& Nadai, 1998; Kanter, 1977; West \& Zimmermann, 1991). The complex process of presenting oneself in interactions and the importance of communicating through action has been described by Goffman (1959), who also included gender in his analyses, e.g. by analyzing how college girls deliberately do mistakes in letters to their boyfriends, since their boyfriend seem to like to explain and teach them (p. 39). Therefore the everyday presentation of self is described as a kind of performance: the individual is an actor, who plays different roles in different interactions and settings. This idea is also present in the work of Kessler/McKenna (1978), they are able to show how the binary gender system is constructed and reproduced in different fields. In the following presentation of interview extracts I want to explore the significance of gender and sexuality in three empirical cases.

\subsection{Officer Smith}

6.1 Officer Smith is 25 years old, holding the lowest rank in the police hierarchy. Smith stresses that already from earliest childhood she wanted to be a police officer, since officers impressed her and commanded her respect. Moreover she adds financial security as a reason to join the police force. Smith describes the police training as hard, but stresses that she came through it quite well. She distances herself from 'dolly girls' and finds that she never tried to get advantages by building up sexual relations with an instructor. Smith underlines that this is, despite the fact that she does not feel sexually attracted to men, an unsuccessful strategy. Furthermore she states that six months in the Bepo ${ }^{[7]}$ have been a hard time for her. There, she believes, she already had a bad starting position as a woman. She left the Bepo and is much happier now working at a police station.

6.2 Smith stresses that in her job she does not put up with anything. Moreover she adds that she fights against unfair treatment by instructors or colleagues and exemplifies this by telling that she even reported a colleague to the authorities for a racist remark. Despite this she positions herself as someone, who always 'welcomes jokes'. If necessary, Smith reports to fight to get respected by citizens, even if she has to apply 
force. In this context she describes a physical confrontation with a man of Arabian heritage, who did not show the respect she expected. Furthermore she presents herself as a nonconformist, who one day goes to work with dread locks and the other day with a bald head. She says that she lives openly as a lesbian and never had any problems with that.

6.3 Concerning police work she stresses to prefer work on the streets to office work. In the interview Smith presents herself as someone, who is able to grab things and grip them tightly and is a reliable colleague. She underlines her strength in dealing with citizens, especially youths. As a single parent she reports to have some advantages, e.g. no night shifts.

6.4 Smith presents herself as someone, who likes to party, is liked by women and in general enjoys adventures. In the interview even police work is often presented as an adventure on the streets. This orientation shows itself in the following citation, in which she talks about her first day as an officer: 'I thought, now it gets started, now there will be a real party and than we were supposed to secure a way to school. I thought that cannot be it, can it?' In her descriptions of daily routine and her statement that there is no routine, since there is always something going on in the district, there is more excitement then regret. Smith explains her preference for street work by stating that this offers a great variety of possible operations and is unpredictable. She contrasts this to station duty and derogatorily speaks of officers working station duty as 'bench warmers'.

\section{Dealings with difference}

6.5 As briefly mentioned above it is very important for Smith to get respected, even if force is needed to get this respect. She states: 'I can also put my fist down and say, people not like this and then it works. That was my choice and I made the choice that there will be consequences.' Smith presents her decision for using force, if necessary to get respect, as her decision. She contrasts this choice to a passive behaviour, which she believes is the cliché men have of female officers. The fact that she positions her behaviour in direct contrast to this cliché makes it very likely that she applies this to set off her behaviour against it.

6.6 The performance of female police officers has been described as a double-bind request by Susan Martin as early as in 1979. The empirical findings of her research, which she conducted within the uniformed police of Washington D.C. ${ }^{[8]}$ show that the female officers shift on a continuum between POLICEwoman and policeWOMAN. This indicates a shifting between a traditionally stereotypical masculine self identification as police officers and a stereotypical self identification as a woman. Martin states that choosing the first identification female police officers are threatening male hegemony, in the second case they are no longer a threat for the traditional police cultures, but get labelled as weak and of no use for the job as a police officer. This indicates that policewomen are often confronted with the difficult task to balance out gender specific expectations and professional demands, which are labelled as 'unfeminine'. I would argue that this is a rather polarized view of women's possibilities of self presentation within the organization. It is obvious that Smith knows about these pitfalls and tries to find her own way around them, which is, one could say, more police than woman. This gets even more obvious, when she distances herself from certain women, who, she says, instrumentalize their femininity and their heterosexuality: 'I mean, to take a weapon apart and learn the mechanisms is not a hard thing ... too lazy for that and then at a party thinking, why not sleep with him [the instructor, S.M.D.], then he is going to give me a good mark. Obviously he thought, well, he did it, why not, there were some nice girls (laughs), but in the end it did not help them.' Considering this citation it is more likely for her to criticize the behaviour of some women than that of an instructor, who accepts sexual offers of his trainees. In taking into account the attractiveness of the girls, Smith seems to understand the behaviour of her instructor. There is no reflection of different power positions of the persons involved and no consideration of the training context. Smith presents a way of dealing with power relations, which she criticizes. The 'girls' strategy only works in a heterosexual context, in which they can play out their sexuality in order to get advantages. Smith is aware of different possibilities of 'doing gender' (West/Zimmermann, 1991) and sexuality within the police. She presents herself as actively choosing a certain way by criticizing the decision of other women who act differently.

6.7 On the one hand Smith stresses the importance of being a good colleague, on the other hand she emphasizes that she has her principles. In this context she states: 'Only because I am wearing a green uniform, I do not have the right to make fun of people, who have a different mentality and a different origin.' Moreover Smith distances herself from 'the boasters' in the Bepo and takes a stand for a male officer, who does not fit in the ideal body scheme of the Bepo and therefore gets excluded. This statement fits well in Connell's (1995) analysis of different forms of masculinities. He differentiates between hegemonic masculinities and subordinated forms of masculinities ( $p .76$ ff.), which are obviously mentioned here.

6.8 In the interview Smith presents herself as alienated of hierarchical police structures and distances herself from some of her colleagues. Smith does not understand her own experience of exclusion within the 
Bepo as a result of being a woman or being a lesbian woman, even though she is contradictory in this matter. She states that 'especially in the Bepo they think that if there comes a girl, she is fair game', and continues: 'They knew it before that they had not chance with me, the guys, so of course from the beginning I left a bad impression.' Even though gender and sexuality are mentioned as a possible reason for exclusion Smith distances herself form the explanation of the representative of women, who assumes that she got discriminated in the Bepo because of her sexual orientation. She rejects that in stating, that there were also others, who faced difficulties in this unit.

\subsection{Officer Brown}

7.1 Officer Brown is 47 years old and holds the lowest rank in the police force, probably due to the fact that she joined the police much later. She tells that she came to the police by coincidence, since she was unemployed and the police was looking for personnel. In the interview she accentuates that her training was too short to compete with officers, who got regular training, which results in feelings of insecurity. She works in a shift with only one other female officer. Brown emphasizes that she suffers form the tone used at the police station and feels excluded. Moreover she describes that her colleagues do not consider her being capable of a lot, they do her work without asking and talk about her in a bad manner, even though she is present.

7.2 Brown tells that she already tried different things to change her situation; she went to the chief inspector to complain about it, tried to get transferred to another station, without success. On top of it she says she got a bad reference, which makes it even more difficult to get transferred. Brown formulates her impression to get excluded from further training; the result of a complaint was that training was offered to her in her vacation. A further difficulty is, following Brown, that she is a single-mother, whose son is often sick, which makes it sometimes difficult for her to fulfil the requests of the job. Brown says that her female colleague is of no help to her; she does not feel supported by her. She describes this policewoman as very 'masculine', who takes part in the talks of male officers and laughs about their jokes. Brown says that there was a female Turkish-German colleague in her shift, who also got excluded. She states that this colleague was of great support to her, since they were able to strengthen each other. But this colleague was able to get transferred after some time.

7.3 Brown sees her strength in her communication skills with citizens. Concerning herself she says: 'I am a quiet type, the citizens like to come to me.' Brown emphasizes her competence in dealing with family problems and issues concerning children. She stresses to be friendly and open to all citizens and to 'always show, that it can be different, or to help them, or to be especially friendly to foreigners.' She contrasts her own conception of being a police officer to that of her colleagues, who would be only interested in facts. Because of this self-description Brown says that she would often question herself, if it had not been better to take a job in the social area.

\section{Dealings with difference}

7.4 A main reason for dissatisfaction with her job is the tone at her police station. She describes a station, in which sexist jokes and remarks are made on a regular basis. She states: 'it is always against female persons, not against concrete ones, but against women in general.' Brown describes an unbearable situation: 'it is like it is in construction, but even worse here; one cannot even repeat it.' The police station is described as the domain of men, in which women face severe difficulties, in Brown's words: 'one has to work harder to receive praise.' Interestingly Brown does not only emphasize her gender, but also her age as a reason for discrimination, since she believes she is no longer attractive for her male colleagues. In this context she describes an interaction with a colleague as follows: 'One colleague just lately told me, you did not even have to open your mouth, just the fact that you are so old, that is enough for then, women anyway. You are no longer acceptable for men there.'

7.5 Brown describes a culture in which women are rather treated as objects than colleagues. Following her statements women get judged by their bodies, e.g. 'too old', 'too fat'. Moreover Brown is alienated by the fact that her superior is tolerating this culture. Interestingly she expresses her believe that the superior cannot afford a different behaviour. In fact he would partially destroy the rules of the male bonding and stop a behaviour, which seems to be quite entertaining for some officers. More than once in the interview Brown massively criticizes her superior, who, in her perception, does not do anything. She states, 'that the boss is taking part that he thinks it is important to take part to hold it together, I do not understand all of this.' Moreover Brown describes that there are two main protagonists in her shift, to whom the other men submit themselves. Even some male colleagues suffer from this culture, Brown states. She says: 'And even a lot of men find this, there are two main protagonists in our police station find them very bad and also suffer, even some male colleagues, who get mobbed by them, who are a little more quiet.' 
7.6 Brown expresses her opinion that the behaviour of women in general is devalued, even if their interventions are of advantage for police work. In Brown's view women have better communication skills than men. She describes this by saying: 'If a woman is detailed for a team man-woman, she is quickly withdrawn, not her, it is a woman. So there is very often no opportunity given at such, because they sometimes really LIKE to do it, I sometimes think. There they can, they are often tough men, who do not want to let go of an opportunity to act a little harder. And this under the cover, they cannot do it, let us do it, even though if women, sometimes in those cases, nothing happens then.' Brown describes a situation, in which women as such are excluded from some operations, because it is argued that they cannot handle them. This is, considering the fact that there are officially no gender specific operations, surprising. Brown assumes that gender is made relevant in order to choose tasks, which her colleagues consider as interesting. The much stressed de-escalation ability of women is no longer valued here, since her colleagues, Brown assumes, sometimes prefer situations escalated. Different ways of intervention are not described as different opinions on police work, but get connected to the gender of the intervening person. In other words: Police interventions are described as determined to the gender of the officers.

7.7 Not only discrimination based on gender, but on ethnicity as well are an issue in the interview with Brown. She tells that her Turkish-German colleague was mobbed until she left the station. In Brown's words: 'but this colleague was really putting her [the Turkish-German colleague, S.M.D.] down. How can that be, that the Turk receives the same salary as we do or has the same power.' Brown stresses her attempts to defend her colleague by saying: 'I have always said: What are you doing with her? She is, they cannot say malicious things about foreigners, when she is sitting amongst them.' Moreover Brown says she has done several things to change the situation and was partially successful, e.g. she does not have to go on patrol with one of her colleagues. But now she states: 'Sometimes it is, that I do not do anything any more, do not fight and say, leave it.'

7.8 On women within the police Brown expresses that there are women, 'who adopt the tone of men' and therefore get respected. Moreover women, who are very successful, are, in her opinion, able to find their place, even though she is contradictory in this point, because she mentions a colleague, who is successful and still not accepted.

7.9 The reflections of Brown are quite similar to Low's (1991) statement concerning the role of policewomen. She assumes that if women cast a complementary role, the dominant male group values them as different, but helpful. Of course it can be questioned here, if Brown is valued at her station at all. Low concludes that this positive valuation of women is thus a result of constructing them as so different, that they are not questioning dominant power relations. Furthermore Low states that this complementary model often causes frustrations for female officers, since women with this traditional complementary behaviour realize that their achievements do not get rewarded, but underestimated. Low concludes that this model also often results in women not working in leading positions within the police. If women try to take over the same role, the dominant group often feels threatened, which can be, following Low, get compensated with the help of status-argumentations, which means that in these argumentations not one single woman seems to be as qualified as men. This often results in female officers desperately try to show that they are as good as their male colleagues. Low concludes that it needs effective promotion of women in this situation. Corresponding with this findings Müller-Francke (1996) concludes, that only if 'male and female behaviour can be enacted by men and women within the police, work and atmosphere will be optimal' (p. 40).

\subsection{Officer Taylor}

8.1 Officer Taylor is 30 years old and holds a middle rank in the police. She was born in East Germany and worked as an industrial electrical engineer before Germany got united. After the reunion Taylor was unemployed and describes it as a coincidence that she applied for the police. Since her training she works in the Bepo, which she describes as her dearest wish, because it allows her to drive heavy equipment, like water-cannon. Taylor states to live openly as a lesbian and stresses that she came out to her colleagues as soon as possible. In Taylor's opinion women are important in the police, because they can deescalate situations and deal with sensitive topics. As her strength Taylor stresses her ability to talk and deal with difficult situations as her weakness she expresses her inability to stay neutral in certain situations, even though she sees neutrality as an important task of police officers. As a reason for her lack of neutrality Taylor presents her situatedness as a lesbian woman in the police, which make her judge differently on some situations than her heterosexual colleagues. Moreover Taylor stresses that an open discrimination of women and homosexual officers is no longer possible within the police and therefore most discriminations are difficult to address. In her opinion homosexuality within the police gets more and more normal, even though she assumes it would be more difficult to be an executive as a lesbian. She stresses to be very happy with her job, because there is no daily routine, but everyday new situations and challenges. 
8.2 Taylor stresses that she has been open of her sexuality from the very beginning. In the interview she describes a situation, in which she came out to her colleagues. She took part in a police intern training, in which a speaker from outside the police obviously talked about homophobia and male dominance within the police. She describes her intervention as follows:

'I said from the back row, one moment please, I cannot leave it like this, because the colleagues, at least the ones, who are present, do not discriminate me. I am a lesbian and I do not get discriminated. Suddenly it was very quiet, I do not know, there was not room to breathe, every one turned around, and I was, so the topic was through.'

8.3 In this coming-out narrative the interviewee tells her colleagues that she is a lesbian and protects them against the assumption that they might be homophobic at the same time. In other words: Taylor is able to express difference to her colleagues and sameness, she is different, but still on their side. A lot of literature concerning homosexuality focuses on the 'coming out' or 'staying in the closet' of lesbian and gay members of organisations (e.g. Hall, 1989; Braun, 1996; Tuschwitz, 1996). Therefore it is not surprising that narratives on how to hide or present one's sexuality were very present in the research presented here. Concerning this issue Tuschwitz (1996) elaborated the situation of gay police officers and comes to the general conclusion that those officers, who are open about their sexual orientation, do face fewer problems at the work place than those being secretive about it. Despite this result it is remarkable that more than half of the participants of Tuschwitz's study do feel discriminated by their colleagues talking behind their backs and by being confronted with homophobic jokes. But it also depends on how homosexuality is displayed within the police, some research results, including the here presented, indicate that the acceptance of homosexual officers often depends on their self presentation or assimilation to gender stereotypes.

Effeminate men and women, who are 'too' masculine, often face problems within the police force and this is not limited to their sexual orientation.

8.4 Despite her view that homosexuality gets more and more accepted in the police, Taylor expresses difficulties to remain neutral in her role as police officer, in certain situations, in which women or homosexuals are involved. In this context she mentions "bad discussions" she had with her colleagues at one Christopher Street Day ${ }^{[9]}$. She describes this incidence as follows: 'Some gay men, who started to make out on the street, where I simply said, okay why not, it is CSD. But it is not permitted; I really had intense discussions with my colleagues, who have a lack of understanding for this. I said, why don't they understand it, but for me it is normal and for them it is a completely different world. This is what I mean, I would have had difficulties to intervene there and to say, ey, guys, moment, because I say it is CSD, they can celebrate. If it is carnival the heteros also do whatever they want, why can't we, at our day, also do what we want?' (313-323).

8.5 This longer interview sequence shows a loyalty conflict, which gets expressed on two levels. Superficially it deals with the knowledge of Taylor that, executing the law, on the one hand she would have to intervene, on the other hand she wants to consider the special occasion, CSD, on which the behaviour is shown. On a deeper level Taylor refers to the fact that police never only executes law, but interpret it. And it is exactly this different interpretation depending on what sexuality is displayed publicly, that Taylor addresses here. The subtext of this sequence reads as a form of loyalty conflict between her role as a police officer and her sense of belonging to a sexual minority.

\section{Concluding remarks}

9.1 In this paper I examined how gender and sexuality were important categories within the German police to negotiate access and jobs in the past. Even though the Berlin police officially promotes diversity today, the here presented interview extracts indicate that gender as well as sexuality can still be relevant categories in everyday interactions. As Müller (1999) stresses for organisations in general there has been an alteration of openly discriminating behaviour to more informal ways of exclusion within organisations, which she calls a 'subtilisation of discrimination'. Argumentations referring to a general ability or inability of women or men for certain jobs are as a rule officially no longer acceptable today. It can be emphasized that today it is more and more difficult to legitimize unequal treatment of organisation members. Nadai and Heintz (1998) underline that exclusions 'are more and more actively established by participants, symbolically stressed or indirectly regulated' (p. 78).

9.2 The analysed interview extracts show a variety of possible experiences and self-presentations of policewomen. The orientation of officer Smith on action, corporeality and the preference of duty on the street shows many similarities to a street cop orientation (Behr, 2000) and an orientation towards hegemonic masculinity, without completely fitting into this picture. In the interview Smith does not present herself as a victim of a male dominated organisation, but stresses her agency, even if she has to act 
against her own colleagues. On the contrary Brown experiences herself being one of the victims of discriminatory practices at her police station. She emphasizes several times that she tried to change this situation by different interventions, but since none of them was successful she expresses tiredness.

Brown's self concept is quite different to that of Smith, since she stresses her difference to certain street cop colleagues, in emphasizing that she is quite, friendly and polite. Finally, officer Brown's self presentation is similar to that of Smith, even though her experience as a lesbian in the police gets more stressed than gender issues within the police. She underlines that there is more and more acceptance for homosexuality in the police, but argues that this might not be the case in higher positions. She expresses loyalty conflicts in situations, in which homosexual citizens are involved and criticizes double standards of her (heterosexual) colleagues. The here presented negotiations seem to be far more complex than the shifting between an identification as POLICEwoman or policeWoman, which has been described in the literature.

9.3 This explorative research shows that there is in fact diversity in uniform. But it has been demonstrated as well that diversity is no normality yet. Difference from the norm of the heterosexual male officer can still be a reason for discrimination and it needs explanation and negotiation by individuals, who do not fit the norm.

\section{Notes}

${ }^{1}$ This article is the result of ongoing research within the Berlin police force, but is heavily based on my thesis, I completed in 2002 (title: Constructions of gender within the Berlin police Force) together with my colleague Katrin Raczynski, who I would like to thank for enriching discussions during this time. I would also like to thank the anonymour referees whose comments helped to improve this paper.

${ }^{2}$ Except some frame legislation, the German police legislation is made on a federal level.

${ }^{3}$ For example: Der Tagesspiegel, 14.02.2000 'Ein bissl frauenfeindlich'; Der Spiegel, 8/1999 'Ganz ungeniert'; Berliner Zeitung, 28.03.2000 'Polizeischule: Rassismus an der Tagesordnung'; Der Tagesspiegel, 28.07.99 'Noch lange kein Spiegelbild der Gesellschaft'.

4Z. B. Holzbecher, Braszeit, Müller und Plogstet (1991), Klotz/Weidmann (2000), Würz (1993)

$5_{\text {http://www. velspol.de }}$

6 I do not argue that the experience described in these interviews is representative for the situation of women and homosexuals in the police in general, since my sample already focused on organised women and homosexual officers.

${ }^{7}$ The Bereitschaftspolizei (Bepo) is spart of the uniformed police, but has spezial duties. The most common form of operation for which the Bepo is deployed are bigger operations, like demonstrations etc. If there are no special operations, the Bepo supports the work of the ordinary uniformed police (see Rupprecht, 1995, p. 81)

${ }^{8} \mathrm{As}$ I mentioned before, a transference of results from one society to another is difficult, but there are indeed some similarities of gender performance of women in formerly male dominated organisations.

${ }^{9}$ The Christopher Street Day in Berlin is a huge event with more than 450000 participants each year. As it is the case for every big event there are numerous police officers, who secure this parade.

\section{References}

ACKER, J. (1991) 'Hierarchies, jobs, bodies: A Theory of Gendered Organizations', Gender \& Society, Vol. 4, pp. 139-158.

ARBEITSGEMEINSCHAFT DER INNENMINISTER DER BUNDESLÄNDER, ARBEITSKREIS 2 (1986)

Frauen im Vollzugsdienst der Schutzpolizei. Erfahrungsberichte über Modellversuche bzw. bisherige

Verwendungen. Hannover: Niedersächsisches Innenministerium.

ARBEITSGEMEINSCHAFT DER INNENMINISTER DER BUNDESLÄNDER, ARBEITSKREIS 2 (1991) Frauen im Vollzugsdienst der Schutzpolizei. Abschließender Bericht an die IMK. Hannover:

Niedersächsisches Innenministerium. 
BEHR, R. (2000) Cop Culture. Der Alltag des Gewaltmonopols. Opladen: Leske+Budrich.

BUTLER, J. (1990) Gender Trouble: Feminism and the Subversion of Identity . Thinking Gender. New York/London: Routledge.

BRAUN, H.-J. (1995) 'Homosexualität in der Polizei. Widerspruch oder Herausforderung?' Materialien der Abteilung Bildung der Gewerkschaft der Polizei. Hilden: Gewerkschaft der Polizei.

BRAUN, H.-J. (1996) 'Homosexualität in der Polizei' in J. Dobler (editor) Schwule, Lesben, Polizei. Vom Zwangsverhältnis zur Zweck-Ehe? Berlin: Verlag rosa Winkel.

BURRELL, G. (1984) 'Sex and Organizational Analysis' Organization Studies, 5 (2), pp. 97-118.

BURRELL, G and HEARN, J. (1989) 'The Sexuality of Organization' in J. Hearn et al. (editors) The Sexuality of Organisation. London/Newbury Park/New Delhi: Sage.

COCKBURN, C. (1993) Blockierte Frauenwege. Wie Männer Gleichheit in Institutionen und Betrieben verweigern. Hamburg: Argument-Verlag.

CONNELL, R.W. (1995) Masculinities. Opladen: Leske+Budrich. University of California Press: Berkeley.

GOFFMAN, E. (1959) The presentation of self in everyday life . New York: Anchor Books.

HALL, M. (1989) 'Private Experiences in the Public Domain: Lesbians in Organisations' in J. Hearn et al. (editors) The Sexuality of Organisation . London/Newbury Park/New Delhi: Sage.

HEINTZ, B. and NADAI, E. (1998) 'Geschlecht und Kontext', Zeitschrift für Soziologie, No. 27, pp. 75-93.

HOLZBECHER, M., BRASZEIT, A., MÜLLER, U. and PLOGSTEDT, S. (1990) Sexuelle Belästigung am Arbeitsplatz. Band 260 der Schriftenreihe des Bundesministeriums für Jugend, Familie, Frauen und Gesundheit. Stuttgart/Berlin/Köln: W. Kohlhammer.

JACKSON, S. (1999) Heterosexuality in question. London: Sage Publications.

KANTER, R.M. (1977) Men and women of the corporation . New York: Basic Books Inc.

KESSLER, S. and MCKENNA, W. (1978) Gender: an ethnomethodological approach. New York: John Wiley \& Sons.

KLOTZ, S. and WEIDMANN, T. (2000) Projektarbeit Frauen In der Berliner Schutzpolizei Gleichberechtigte KollegInnen oder geduldete MitarbeiterInnen. Berlin: Heft 22 des FB 3 der Fachhochschule für Verwaltung und Rechtspflege.

LEIDNER, R. (1991) 'Serving Hamburgers and Selling Insurances: Gender, Work and Identity in interactive Service Jobs', Gender \& Society, Vol. 5, pp. 154-177.

LOW, P.C. (1991) 'Are women that different?', Policing, Vol. 7, pp. 15-21.

MARTIN, S.E. (1979) 'Policewomen and Policewomen: Occupational Role Dilemmas and Choices of Female Officers', Journal of Police Science and Administration, Vol. 14, pp 314-323.

MÜLLER, U. (1993) 'Sexualität, Organisation und Kontrolle' in B. Aulenbacher and M. Goldmann (editors) Transformationen im Geschlechterverhältnis. Beiträge zur industriellen und gesellschaftlichen Entwicklung . Frankfurt/New York: Campus.

MÜLLER, U. (1999) 'Geschlecht und Organisation. Traditionsreiche Debatten - aktuelle Tendenzen' in Nickel, Hildegard Maria et al. (editor) Transformation - Unternehmensre-organisation Geschlechterforschung. Opladen: Leske+Budrich.

MÜLLER-FRANKE, W. (1996) 'Frauen In der Polizei - Maskottchen oder Partnerinnen?', Kriminalpolitik, Vol. 4, pp. 38-42.

RASTETTER, D. (1994) Sexualität und Herrschaft in Organisationen. Opladen: Westdeutscher Verlag.

RUPPRECHT, R. (1995) Polizei Lexikon. Heidelberg: Kriminalistik Verlag.

SCOTT, J.W. (1986) 'Gender: A useful category of historical analysis', The American Historical Review, Vol. 91, No. 5, pp. 1053-1075. 
STRAUSS, A. \& CORBIN J. (1996). Grounded Theory: Grundlagen Qualitativer Sozialforschung. Weinheim: Beltz, Psychologie Verlags Union.

TUSCHWITZ, N. (1996) ‘Schwule Polizisten' in J. Dobler (Editor) Schwule, Lesben, Polizei. Vom Zwangsverhältnis zur Zweck-Ehe? Berlin: Verlag rosa Winkel

WEST, C. \& ZIMMERMAN, D. (1991) Doing gender. In J. Lorber \& S.A. Farell (Hrsg.), The Social Construction of Gender (S. 13-37). Newbury Park: SAGE Publication Inc.

WETTERER, A. (1993) Professionalisierung und Geschlechterhierarchie. Vom kollektiven Frauenaussschluss zur Integration mit beschränkten Möglichkeiten. Kassel: IAG FG Selbstverlag.

WILZ, S. (2002) Organisation und Geschlecht. Opladen: Leske+Budrich.

WITZEL, A. (1985). Das problemzentrierte Interview. In G. Jüttemann (Ed.), Qualitative Forschung in der Psychologie (pp. 227-255). Weinheim, Basel: Beltz-Verlag.

WÜRZ, A. (1993). Frauen im Vollzugsdienst der Schutzpolizei . Frankfurt a. M.: Verlag Peter Lang GmbH.

YEARLEY, Clifton K. (1997) 'Bureaucracies' in F. N. Magill (editor) International Encyclopedia of Sociology Volume 1. London/Chicago: Fitzroy Dearborn Publishers.

\section{Articles from magazines without naming the author:}

Gefahr für die weibliche Schutzpolizei (1953), Berliner Polizei , Nr. 11.

Die letzte Wespe geht (1986), Deutsche Polizei, Nr. 12.

Die Frau in der Polizei (1954), Berliner Polizei, Nr. 2. 